Original

\title{
General public and workers exposure to high-frequency electric fields in spanish hospitals
}

\author{
Exposición de trabajadores y usuarios a campos eléctricos de alta frecuencia \\ en hospitales españoles
}

\section{Alberto Caldés Casas², Fanny Serapio Fernández', María del Carmen Bueloha', Rodrigo Picos Gayá', Carlos Campillo Artero²}

1. Physics Department, Balearic University. Palma, Balearic Islands, Spain.

2. Health Services Evaluation, Balearic Health Service. Palma, Balearic Islands, Spain.

Recibido: 21-12-12

Aceptado: 24-01-13

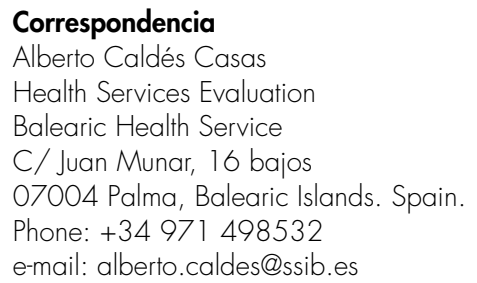

Funding: This Project was financed by a fund of the 2010 National Health Service Strategies of the Spanish Ministry of Health and Social Policy, adopted by the Interterritorial Board to support the implementation of the Strategy on Patient Safety of the Spanish NHS. It has also been partially supported by Mapfre Foundation, under the "Becas de Investigación (Research Grants) 2010" program.

Abstract

Introduction: Electromagnetic fields (EMF) are commonly used in hospitals to detect and treat certain diseases or ailments, exposing healthcare workers daily to such fields and casting doubts about workers and patients safety.

Objectives: To quantify the actual exposure to high-frequency electric fields of workers and public hospitals users in the Balearic Islands (Spain) and the compliance with the references levels established by the International Commission on Non-Ionizing Radiation Protection (ICNIRP).

Material and Metbods: High-frequency radiation exposure levels were measured in different areas and compared with ICNIRP levels and Spanish regulation, using a broadband field strength meter and a spectrum analyzer.

Results: 1,290 measurements were performed obtaining a median electric field of $0.31 \mathrm{~V} / \mathrm{m}$ (1st quartile: $0.16 \mathrm{~V} / \mathrm{m}$; 3rd quartile: $0.67 \mathrm{~V} / \mathrm{m}$ ). Users and workers are exposed to electric fields from $0.19 \mathrm{~V} / \mathrm{m}$ to 0.25 $\mathrm{V} / \mathrm{m}$ in all areas, but Rehabilitation and Radiology. In the former, the patients (not under microwave therapy) are exposed to EMF between $1.87 \mathrm{~V} / \mathrm{m}$ and $25.71 \mathrm{~V} / \mathrm{m}$.

Discussion and conclusions: Although effective electric field values are lower than the reference levels, measures should be taken to reduce exposure of especially sensitive people (infants, children, pregnant women,...) and ensure regular monitoring of the exposure.

Med Segur Trab (Internet) 2013; 59 (230) 15-25

Key words: EMF assessment; electric field exposure; bospital environment; non-ionizing radiation exposure; safety. 


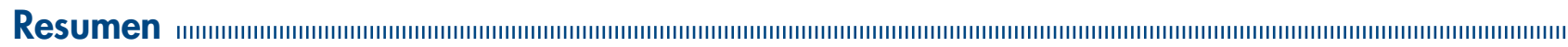

Introducción: Los campos electromagnéticos (CEM) se utilizan con frecuencia en los hospitales para detectar y tratar ciertas enfermedades o dolencias, exponiendo diariamente a los trabajadores sanitarios a esos campos y sembrando dudas sobre la seguridad de trabajadores y pacientes.

Objetivos: Cuantificar la exposición real de trabajadores y usuarios de los hospitales públicos de las Islas Baleares (España) a campos eléctricos de alta frecuencia y el cumplimiento de los niveles de referencia establecidos por la Comisión Internacional de Protección contra la Radiación No Ionizante (ICNIRP).

Material y métodos: Se midieron los niveles de exposición a radiaciones de alta frecuencia y se compararon con los niveles de ICNIRP y normativa española, usando un equipo de banda ancha y un analizador de espectro.

Resultados: Se realizaron 1,290 mediciones obteniendo una mediana del campo eléctrico de $0.31 \mathrm{~V} / \mathrm{m}$ (1er cuartil: $0.16 \mathrm{~V} / \mathrm{m}$; 3er cuartil: $0.67 \mathrm{~V} / \mathrm{m}$ ). Usuarios y trabajadores están expuestos a campos eléctricos de $0.19 \mathrm{~V} / \mathrm{m}$ a $0.25 \mathrm{~V} / \mathrm{m}$ en todas las áreas, excepto Rehabilitación y Radiología. En la primera, los pacientes (no tratados con microondas) están expuestos a CEM entre $1.87 \mathrm{~V} / \mathrm{m}$ y $25.71 \mathrm{~V} / \mathrm{m}$.

Discusión y conclusiones: Aunque los valores eficaces de campo eléctrico están por debajo de los niveles de referencias, se deben tomar medidas para reducir la exposición de personas especialmente sensibles (bebés, niños, gestantes,...) y asegurar un control periódico de la exposición.

Med Segur Trab (Internet) 2013; 59 (230) 15-25

Palabras clave: evaluación CEM; exposición a campos eléctricos; ambiente bospitalario; exposición a radiaciones no ionizantes; seguridad. 


\section{INTRODUCTION}

The technological development applied to healthcare improves the quality of life of citizens. The increasing development of devices and communications media within the healthcare system increases flexibility and mobility that could improve the quality of care, reduce costs of care per patient, and increase efficiency of health services delivered. It also entails the use of artificial electromagnetic radiation devices which causes a constant exposure to ionizing and non-ionizing radiations of both health care professionals and patients.

Short-term electromagnetic radiation safety has been shown in different studies. Although virtually ignored in the field of clinical safety, it is in fact another cornerstone of the legal basis of the regulations of exposure to these fields, restricted to frequencies between 0 and $300 \mathrm{GHz}$ (non-ionizing radiation). These limits are based on short-term or immediate effects, like muscle stimulation by induced currents, tissue heating due to energy absorption, or burns caused by electric discharges ${ }^{1}$.

Regarding its long-term health effects, risk of cancer of exposed individuals is one of the most important. There is consistent data showing a slightly higher risk of leukemia among children living close to power lines. Moreover, the International Agency for Research on Cancer $^{2}$ has recently classified radiofrequency electromagnetic fields as possibly being carcinogenic to humans (Group 2B), based on an increased risk for glioma, a malignant type of brain cancer, associated with wireless phone use ${ }^{3}$, as well as other effects on short-term wellness ${ }^{4}$.

On the other hand, in a large study of the risk of brain tumors in relation to mobile phones, which included substantial numbers of subjects who had used mobile phones for 5-10 years, no increase in the risk of either glioma or meningioma was found to be associated with them. However, biases and methodological pitfalls limit the strength of the conclusions that can be drawn from these analyses and prevent to establish causal relationships ${ }^{3}$. These inconclusive results are a central tenet of virtually all of the studies that have been carried out in this field.

\section{REGULATIONS}

Initially, each country is responsible for selecting its own national standards against exposure to electromagnetic radiation. However, most specific standards are based on the ICNIRP recommendations that set up two different groups to determine exposure limits ${ }^{1}$ : Occupational, which consists of adults who are generally exposed to known conditions and are trained to be aware of potential risk to take appropriate precautions; and General public, comprising individuals of all ages and varying health status. More often than not, the public is not aware of their exposures to EMF. Therefore, they cannot be expected to take reasonable precautions to minimize or avoid exposure. For these reasons, more stringent exposure restrictions have been adopted for the general public than for occupational population. A comparison between these two values is shown in Figure 1. 
Figure 1. ICNIRP reference levels for occupational and general public exposure to time-varying electric fields

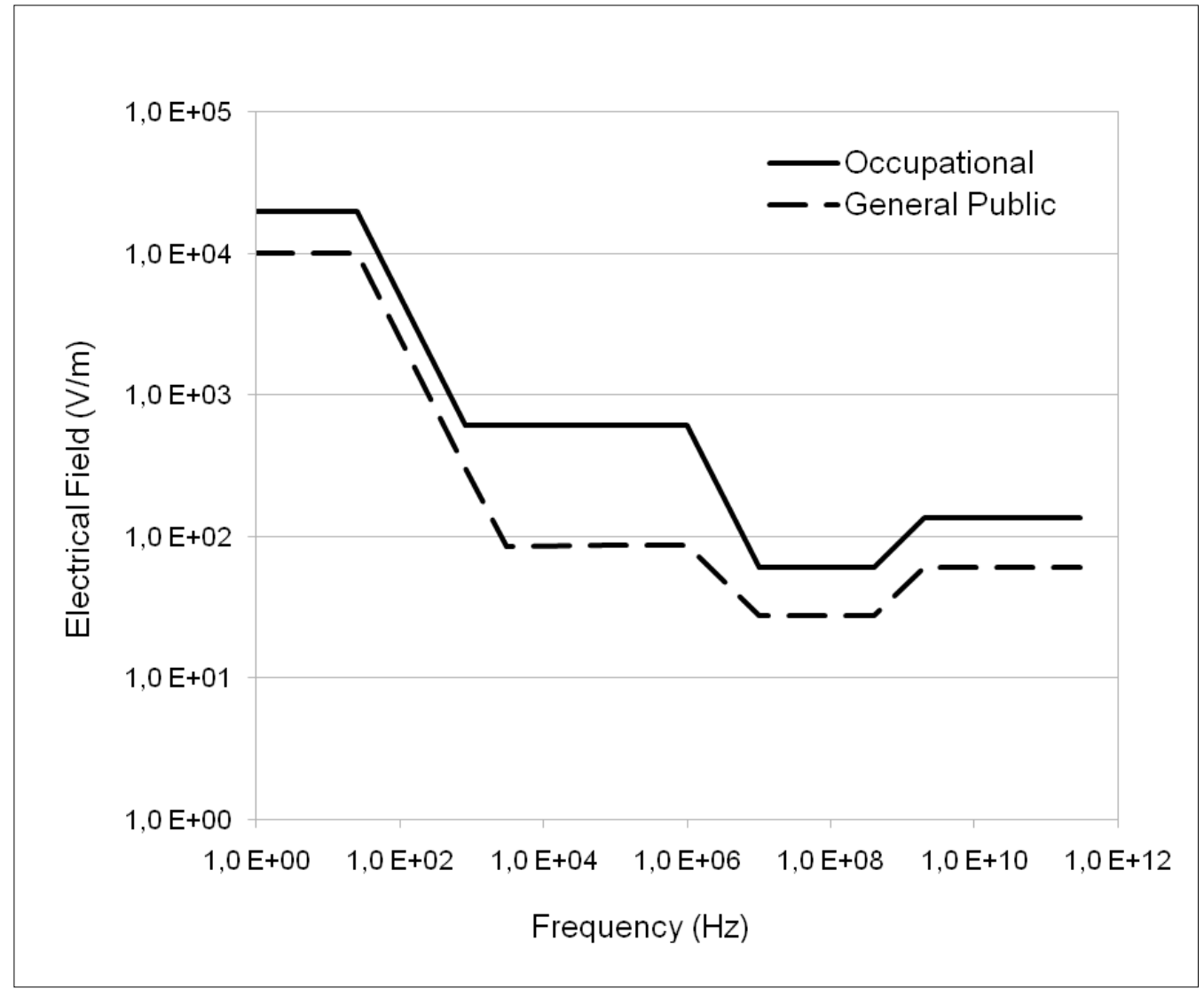

ICNIRP international limits have been taken up in Europe by two regulations: The Council Recommendation 1999/519/EC $\mathrm{EC}^{5}$, focusing on the environment, and the Directive $40 / 2004 / \mathrm{EC}^{6}$, devoted to the working environment. This Directive applies only to workers, and excludes long-term effects because according to current scientific evidence it is still not considered sufficient to cause harm.

In Spain, the applicable legislation ${ }^{7}$ makes no distinction of limits between occupational and general public. It also sets the limit values at the ICNIRP Guidelines ${ }^{1}$ for general public.

\section{Radiation sources in hospitals}

In a hospital environment, there are two types of electromagnetic radiation generators, both serving for different purposes: Information and communications technology (ICT), they are a set of devices that improve quality of life by means of storage, processing, and diffusion of information (patient history, test results, monitoring, etc.). The most common ICT devices/equipment in a hospital are computers, mobile phones, data display screen, television, radio, and mobile antennas; and Diagnosis, Therapy and Rehabilitation devices: they encompass a broad array of devices. In this work, we aim to analyze the exposure to high-frequency electric field radiation generated by the following devices:

Magnetic Resonance Imaging (MRI), it generates high-strength static magnetic fields (between 0.15 and $7 \mathrm{~T}$ ) and gets information on the structure and body composition to detect changes in tissues (cancer and other diseases).

Microwave-device (MW), it is a unit that operates at a frequency of $2,450 \mathrm{MHz}$. Microwaves do not produce changes in molecular tissues structure, but they transform energy into heat to trigger tissue regeneration. 
Short-wave device, it is a unit based on high-frequency electrotherapy that uses a radiofrequency of $27.12 \mathrm{MHz}$. It heats tissues to stimulate regeneration, reabsorbing edemas and reducing inflammation.

Ultrasound device, it is a unit that uses cyclic compression and expansion of waves frequency between 1 and $3 \mathrm{MHz}$. It is used for diagnosis and to treat various diseases, including trauma disorders, various forms of cancer, etc.

In this paper we report some of the results of the study carried out under the coordination of the Health Services Evaluation Unit of the Balearic Health Service to identify and quantify the risks to which workers and patients may be exposed in connection to non-ionizing radiations. Specifically, we present the results of the measurements of the electric field in the more relevant areas of the hospitals in that region.

\section{MATERIAL AND METHODS}

The first step is to gather information on which radiation sources (medical equipment, antennas and mobile phones,...) need to be evaluated. These information was obtained both by visual examination of the area and by analyzing the radio-electric spectrum. Another factor to be considered is the environment: areas where the general public and hospital personnel are exposed have to be selected. Some authors analyzed the exposure of healthcare workers to low-frequency radiation ${ }^{8-10}$. In our case, we are aiming at highfrequency radiation, so their results in terms of the more exposed areas are not directly applicable. We have to make sure that when measurements are made the radiation source produces representative levels of emission of its normal operation.

Before making any measurement, it is necessary to keep in mind the type of radiation and the frequency range within the area being evaluated. In this project we used different devices:

- Spectrum analyzer: the Rohde \& Schwarz FSH3 (Munich, Germany) is a device that displays characteristics of each spectral component in a specific range of frequencies $(100 \mathrm{kHz}-3 \mathrm{GHz})$. It is used to identify the type of radiation to which someone is exposed (microwave, radio,...) at a particular point.

- Radiation meter: this device measures medium-high range of frequencies and stores electric field strength and/or magnetic values. The measurements were performed using a Broadband Field Meter Narda Safety Test Solutions (New York, USA) NBM-550, with an EF0391 probe (100 kHz-3 GHz).

The measurements were carried out with the antenna at a height of $1.5 \mathrm{~m}$ from the floor with a non-conducting tripod. A first fast exploration of the area was performed by measuring instantaneous samples in order to identify hot (high radiation levels) points. Then, effective field strength measurements were made over a period of 6 minutes at these points of increased radiation. Broadband devices with isotropic probes were used to characterize the environment quickly, measuring the total field.

\section{Location of the emplacements}

This work has focused on the following public hospitals in the Province of the Balearic Islands (Spain):

Son Dureta University Hospital (Palma), the former referral hospital of the Balearic Islands, is located in the city of Palma, in the island of Mallorca and attends the largest influx of island population (330,000 inhabitants approximately).

Son Espases University Hospital (Palma), the new referral hospital of the Balearic Islands, is also located in Palma, serving the same population than Son Dureta. 
Son Llàtzer Hospital (Palma) is another hospital close to Palma. It contains all the services (radiology, rehabilitation, emergency, outpatient areas, MRI,...).

Manacor Hospital (Manacor) is a regional hospital, covering the eastern part of Mallorca, and serving around 150,000. It provides all the services, but MRI.

Inca Regional Hospital (Inca) is just outside the center of Inca population in the island of Mallorca and it takes care for providing health service to more than 115,000 people. The hospital consists of a single building, where it was measured radiology, rehabilitation, emergency and outpatient areas.

Can Misses Hospital (Ibiza) is a regional hospital located outside the centre of Eivissa city in the island of Ibiza and serves more than 140,000 inhabitants. Can Misses Hospital has a main building with different zones (emergency, rehabilitation, outpatient areas, ...) and an annex which contains nephrology and hemodialysis units.

Formentera Hospital is a small hospital in the island of Formentera. This health center serves a population of more than 10,000 people and it has only a main building with different zones (emergency, rehabilitation, outpatient areas,...).

Mateu Orfila Hospital (Maó) is a hospital serving the whole population of the island of Menorca, which is around 100,000 people, and it's a full-featured hospital, containing all the services (radiology, rehabilitation, emergency, outpatient areas, MRI,...).

\section{RESULTS}

A total of 1,290 measurements were made from April 2009 until the end of November 2011 and they were distributed in different areas of all hospitals. The median of the electric field measurements was $0.31 \mathrm{~V} / \mathrm{m}\left(1^{\text {st }}\right.$ quartile: $0.16 \mathrm{~V} / \mathrm{m}$; $3^{\text {rd }}$ quartile: $\left.0.67 \mathrm{~V} / \mathrm{m}\right)$.

Related to the types of radiation sources measured, ICT were located mainly in areas where general public was exposed (Hall, Patient Care Point, Waiting rooms,...) and administrative services, while medical devices were located mostly in areas where health workers were exposed. Table I contains the spatial average of the root mean square (rms) values for each measured area in each hospital. Table II contains the spatial average of the maximum values for the same areas than before, while Table III contains the single maximum values for each hospital and area.

\section{Outside area}

The purpose of analyzing the outside area was to identify external radiation sources (radar, television, radio or telephone antennas,...) that may exceed the limits set by regulation. The measurements were carried out on the perimeter of each hospital. For analysis purposes, we have considered all known radiation sources in a $2 \mathrm{~km}$ radius, but for the Formentera case, where we have considered sources up to $20 \mathrm{~km}$.

The maximum value of the electric field "E" of all hospitals measured in this area was $2.13 \mathrm{~V} / \mathrm{m}$, and it corresponds to a point in the Son Espases Hospital. The average value was $0.25 \mathrm{~V} / \mathrm{m}$, with a standard deviation $\sigma=0.14 \mathrm{~V} / \mathrm{m}$. The highest $\mathrm{rms}$ values were obtained in Son Llàtzer $(0.35 \mathrm{~V} / \mathrm{m})$ and Son Espases $(0.56 \mathrm{~V} / \mathrm{m})$.

\section{Common areas}

These common areas include the cafeteria, the hall and the waiting rooms, and they were included in the study due to the continued exposure of general public and health professionals. In this region we made high-frequency measurements and frequency spectrum analysis. The maximum value of the electric field "E" of all hospitals obtained in this area was $2.14 \mathrm{~V} / \mathrm{m}$, and was measured in the Inca Regional Hospital. The average value was $0.19 \mathrm{~V} / \mathrm{m}$, with a standard deviation $\sigma=0.05 \mathrm{~V} / \mathrm{m}$. 


\section{Emergency Department}

This was a critical area to be studied, since there are daily periods of time when the emergency department is crowded. Thus, health workers have to place extra beds in corridors to serve more patients and in these corridors there are radiation sources (wifi antennas, computers, printers, etc.).

The maximum value of the electric field "E" of all hospitals measured in this area was $1.42 \mathrm{~V} / \mathrm{m}$, and was obtained in the Son Llàtzer Hospital, close to a monitor. The average value was $0.23 \mathrm{~V} / \mathrm{m}$, with a standard deviation $\sigma=0.11 \mathrm{~V} / \mathrm{m}$.

\section{Radiology}

In this area, medical explorations are performed to identify diseases. This area is especially important because several X-ray equipment (computed axial tomography, mammography, orthopantomography, etc.) coexists there with the MRI. We analyzed both the X-ray control zone (where health workers are exposed) and the interior area during scanning of patient.

The MRI is the most important contributor to the electromagnetic radiation levels. From the 8 considered hospitals, 5 of them have one or more MRI units, totalling $71.5 \mathrm{~T}$ MRI and $13 \mathrm{~T}$ unit. We have measured both close to the end of the bore and at $1 \mathrm{~m}$, and also in the control room.

The maximum value of the electric field "E" of all hospitals obtained in this area was 10.17 V/m, and was obtained in the $3 \mathrm{~T}$ MRI, near the bore end, of the Son Espases Hospital. The average rms value was $0.55 \mathrm{~V} / \mathrm{m}$, with a standard deviation $\sigma=0.35 \mathrm{~V} / \mathrm{m}$.

\section{Rehabilitation Zone}

Rehabilitation was also important to investigate due to the simultaneous presence of many patients inside the same room where different devices (microwave, magnetotherapy, laser, ultrasounds, electrotherapy, etc.) are deployed, separated only by curtains. Thus, while the patient is treated, health workers and general public are constantly exposed because the room is not fully electromagnetic shielded and corridors are close to radiation sources.

Measurements were made in rooms adjacent to the EMF emitting equipment, on treatments tables inside the gym and the physiotherapy control desk.

The maximum electric field average value "E" measured was $78.7 \mathrm{~V} / \mathrm{m}$ at the Son Espases Hospital, and occurred at a treatment table in an adjacent room when both microwave devices were active and in full power. Moreover, in the staff break room located close to the MW boxes, a maximum value of $72.3 \mathrm{~V} / \mathrm{m}(\mathrm{rms}$ of $44.90 \mathrm{~V} / \mathrm{m})$ was obtained. The average rms value for all hospitals was $3.96 \mathrm{~V} / \mathrm{m}(\sigma=1.47 \mathrm{~V} / \mathrm{m})$.

If we distinguish between patient (not under MW therapy) and worker exposure, the former are exposed to fields in a range between $1.87 \mathrm{~V} / \mathrm{m}$ and $25.71 \mathrm{~V} / \mathrm{m}$. On the other hand, the professionals are exposed to fields ranging from $1.70 \mathrm{~V} / \mathrm{m}$ up to $44.90 \mathrm{~V} / \mathrm{m}$.

It has to be noted that Can Misses, Formentera and Inca Hospitals have one or two short-wave equipment separated by curtains between microwave devices. The radiation generated by these units is much smaller than that generated by the microwave units. The maximum rms value of the electric field " $E$ " measured was $1.5 \mathrm{~V} / \mathrm{m}$ and it occurred at Can Misses Hospital when two short-wave generators were active and in full power.

\section{Inpatient area}

Rooms, nursing stations and waiting rooms were measured in this area. The maximum electric field average value "E" measured was $1.77 \mathrm{~V} / \mathrm{m}$ and it occurred the Son Espases Hospital. The average rms value was $0.22 \mathrm{~V} / \mathrm{m}$, with a standard deviation $\sigma=0.05 \mathrm{~V} / \mathrm{m}$. 


\section{Intensive care unit (ICU)}

This area provides comprehensive and continuous care for persons who are critically ill and who can benefit from treatment. We can find equipment for the constant monitoring of bodily functions, telemetry,...

The maximum electric field average value "E" occurred at the Son Espases Hospital and Can Misses Hospital, both with measured values of $0.94 \mathrm{~V} / \mathrm{m}$. The average rms value was $0.16 \mathrm{~V} / \mathrm{m}$, with a standard deviation $\sigma=0.08 \mathrm{~V} / \mathrm{m}$.

\section{DISCUSSION}

Although exposure to non-ionizing radiation may produce thermal effects (tissue heating) on the human body, while exposure values are below the reference levels set by the ICNIRP, there are not short term adverse effects on human health. Potential long term effects are still under study.

All rms results obtained in Son Espases, Son Dureta, Manacor, Son Llàtzer, Mateu Orfila, Inca, Formentera, and Can Misses Hospitals were far below of reference levels included both in the ICNIRP recommendations ${ }^{1}$ and Spanish legislation ${ }^{7}$.

Table I shows a comparison of the different spatial average measured rms values for each area in all hospitals. The maximum rms value were $6.59 \mathrm{~V} / \mathrm{m}$, which is approximately ten times lower than the value allowed by regulation $(61 \mathrm{~V} / \mathrm{m})$ for the electric field in the ICNIRP recommendation.

Table I. Spatial mean of the root mean square (RMS) electric field values in each area of all hospitals (in V/m)

\begin{tabular}{cccccccc}
\hline Hospital & Outside & $\begin{array}{c}\text { Common } \\
\text { areas }\end{array}$ & $\begin{array}{c}\text { Emergency } \\
\text { Department }\end{array}$ & Rehabilitation & Radiology & Inpatient area & ICU \\
\hline Can Misses & 0.16 & 0.25 & 0.19 & 2.36 & - & 0.23 & 0.19 \\
Manacor & 0.19 & 0.13 & 0.47 & 3.59 & 0.07 & 0.17 & 0.11 \\
Son Dureta & 0.16 & - & - & 6.59 & 0.95 & - & - \\
Inca & 0.24 & 0.20 & 0.27 & 2.70 & 0.29 & 0.16 & 0.10 \\
Son Llàtzer & 0.35 & 0.20 & 0.18 & 3.20 & 0.40 & 0.22 & 0.29 \\
Formentera & 0.12 & 0.25 & 0.16 & 3.24 & - & - & - \\
Mateu Orfila & 0.22 & 0.12 & 0.15 & 5.57 & 0.81 & 0.21 & 0.10 \\
Son Espases & 0.56 & 0.15 & 0.21 & 4.44 & 0.78 & 0.30 & 0.19 \\
Average & 0.25 & 0.19 & 0.23 & 3.96 & 0.55 & 0.22 & 0.16 \\
Standard & 0.14 & 0.05 & 0.11 & 1.47 & 0.35 & 0.05 & 0.08 \\
deviation $(\sigma)$ & & & & & & & \\
\hline
\end{tabular}

Table II presents a comparison of the different spatial average measured maximum values for each area in all hospitals. The maximum value is $9.58 \mathrm{~V} / \mathrm{m}$, which is approximately six times lower than the value allowed by regulation $(61 \mathrm{~V} / \mathrm{m})$ for the electric field. 
Table II. Spatial mean of the maximum electric field values in each area of all hospitals (in V/m)

\begin{tabular}{cccccccc}
\hline Hospital & Outside & $\begin{array}{c}\text { Common } \\
\text { areas }\end{array}$ & $\begin{array}{c}\text { Emergency } \\
\text { Department }\end{array}$ & Rehabilitation & Radiology & Inpatient area & ICU \\
\hline Can Misses & 0.83 & 0.73 & 0.42 & 5.34 & - & 0.47 & 0.60 \\
Manacor & 0.52 & 0.46 & 0.67 & 7.70 & 0.34 & 0.36 & 0.20 \\
Son Dureta & 0.31 & - & - & 8.68 & 1.84 & - & - \\
Inca & 0.37 & 0.44 & 0.40 & 6.60 & 0.60 & 0.46 & 0.32 \\
Son Llàtzer & 0.57 & 0.76 & 0.49 & 4.72 & 0.67 & 0.43 & 0.55 \\
Formentera & 0.39 & 0.56 & 0.40 & 8.41 & - & - & - \\
Mateu Orfila & 0.32 & 0.39 & 0.37 & 7.17 & 1.33 & 0.49 & 0.36 \\
Son Espases & 0.76 & 0.49 & 0.47 & 9.58 & 1.29 & 0.46 & 0.43 \\
Average & 0.51 & 0.55 & 0.46 & 7.28 & 1.01 & 0.45 & 0.41 \\
Standard & 0.20 & 0.14 & 0.10 & 1.67 & 0.57 & 0.05 & 0.15 \\
deviation $(\sigma)$ & & & & & & & \\
\hline
\end{tabular}

Finally, Table III contains the single measurement absolute maxima for each area. The maximum value in this case is $78.70 \mathrm{~V} / \mathrm{m}$, which does exceed the maximum value allowable $(61 \mathrm{~V} / \mathrm{m})$. It has to be noted that, in this case, the value corresponds to a point close to a MW, which is, in fact, designed to produce a biological effect and, thus, it has to be near the limits. Nevertheless, it requires medical control, and it is also convenient to arrange the MWs in such a manner that they do affect as little as possible the workers and other patients.

Table III. Absolute maximum electric field values in each area of all hospitals (in $\mathrm{V} / \mathrm{m}$ )

\begin{tabular}{cccccccc}
\hline Hospital & Outside & $\begin{array}{c}\text { Common } \\
\text { areas }\end{array}$ & $\begin{array}{c}\text { Emergency } \\
\text { Department }\end{array}$ & Rehabilitation & Radiology & Inpatient area & ICU \\
\hline Can Misses & 1.56 & 1.50 & 0.52 & 46.78 & - & 0.71 & 0.94 \\
Manacor & 0.90 & 0.88 & 1.32 & 62.50 & 0.43 & 0.61 & 0.20 \\
Son Dureta & 0.69 & - & - & 15.06 & 3.61 & - & - \\
Inca & 0.57 & 2.14 & 0.62 & 37.05 & 7.87 & 0.62 & 0.32 \\
Son Llàtzer & 1.29 & 2.02 & 1.42 & 24.21 & 0.67 & 1.25 & 0.80 \\
Formentera & 0.41 & 1.97 & 0.47 & 28.74 & - & - & - \\
Mateu Orfila & 0.59 & 0.69 & 0.59 & 29.59 & 7.30 & 0.71 & 0.45 \\
Son Espases & 2.13 & 1.86 & 1.24 & 78.70 & 10.17 & 1.77 & 0.94 \\
Average & 1.02 & 1.58 & 0.88 & 40.33 & 5.01 & 0.95 & 0.61 \\
Standard & 0.60 & 0.58 & 0.42 & 21.26 & 4.05 & 0.47 & 0.33 \\
deviation $(\sigma)$ & & & & & & &
\end{tabular}

In the outside area, the highest rms values were obtained in Son Espases $(0.56 \mathrm{~V} / \mathrm{m})$ and Son Llàtzer $(0.35 \mathrm{~V} / \mathrm{m})$ because they are located close to the capital. To discriminate between the different emitters, we used the spectrum analyzer to evaluate the frequency components, and it was found that the main contributors were TV emitters (whose frequency range is between $470 \mathrm{MHz}-861 \mathrm{MHz}$ ), and GSM (890 MHz - $960 \mathrm{MHz}$ ) and UMTS base stations $(2.1 \mathrm{GHz}-2.2 \mathrm{GHz})$.

The maximum values obtained in the common areas in Formentera, Son Espases and Son Llàtzer are caused by the continuous use of cellular phones by the patients, except in the case of Formentera, where the maxima are due to the closeness to the rehabilitation area and the use of cordless phones.

The average rms value of electric field " $E$ " in the radiology department was $0.55 \mathrm{~V} / \mathrm{m}$ $(\sigma=0.35 \mathrm{~V} / \mathrm{m})$. The high value of $\sigma$ is due to the inclusion of hospitals with MRI and without MRI. In this case, however, the measured values range from $0.07 \mathrm{~V} / \mathrm{m}$ (Manacor) to $0.95 \mathrm{~V} / \mathrm{m}$ (Son Dureta). It must be noted that workers are shielded in the control room while they make radiographic examinations. 
Related to rehabilitation areas, the radiation values of microwave equipment was higher at Son Dureta and Mateu Orfila Hospitals $(6.59 \mathrm{~V} / \mathrm{m}$ and $5.57 \mathrm{~V} / \mathrm{m})$ in comparison to other hospitals. The most probable explanation is that this equipment was older than in the other places, where the measurements were in the range of $2.36-4.44 \mathrm{~V} / \mathrm{m}$. None of the measured rms values in the rehabilitation area has exceeded the limits established by ICNIRP guidelines, though at the Son Espases Hospital there was a point where the maximum $(78.70 \mathrm{~V} / \mathrm{m})$ did actually exceed the limit $(61 \mathrm{~V} / \mathrm{m})$. However, in pediatric rehabilitation wards of the Son Llàtzer Hospital and Mateu Orfila Hospital, we have obtained maximum values of $15.33 \mathrm{~V} / \mathrm{m}$ and $13.02 \mathrm{~V} / \mathrm{m}$, and $\mathrm{rms}$ values of $10.54 \mathrm{~V} / \mathrm{m}$ and $9.15 \mathrm{~V} / \mathrm{m}$, respectively. It has to be noted that these values are below the ICNIRP recommendations, but it is also worth noticing that these same recommendations only apply to adult, healthy people, and that we have no information on the effects of lower fields on infants or children. The professionals in rehabilitation areas are exposed to fields ranging from $1.70 \mathrm{~V} / \mathrm{m}$ up to $44.90 \mathrm{~V} / \mathrm{m}$, which are higher than those in MRI, ranging between $0.23 \mathrm{~V} / \mathrm{m}$ and $7.57 \mathrm{~V} / \mathrm{m}$.

\section{CONCLUSIONS}

The areas where the fields are higher are Rehabilitation and Radiology, because of the use of MW and MRI, respectively. In fact, in the latter areas, the maximum values were around $0.5 \mathrm{~V} / \mathrm{m}$, while in the former maximum values higher than $25 \mathrm{~V} / \mathrm{m}$ were consistently obtained, due to the presence of MW equipment. In all the other areas, low values were obtained $(0.19 \mathrm{~V} / \mathrm{m}$ to $0.25 \mathrm{~V} / \mathrm{m})$ for both patients and workers.

Nevertheless, it is recommended to take some measures to minimize or reduce the exposure to microwaves radiation:

- MW emitting equipment must be inside rooms that are shielded from outside. An effective way to achieve this isolation is using faraday cages. This is done by using metallic meshes with a maximum pitch of $6 \mathrm{~mm}$, connected to electric ground.

- Location and orientation of the MW equipment must be such that it minimizes the exposition of professionals and other patients, especially those that are most sensitive, like children and pregnant women.

Finally, it should be mentioned the importance that measuring radiation periodically has several benefits, among which the most notable are encouraging an Electromagnetic Compatibility control including any electromagnetic interference and act efficiently in case of exceeding the limits set by law, and also the creation of an exhaustive measures history, which would allow to detect causes quickly in the case that limit values would be reduced in regulations or new health effects would be discovered.

\section{BIBLIOGRAPHIC REFERENCES}

1. International Commission on Non-Ionizing Radiation Protection. Guidelines for limiting exposure to time-varying electric, magnetic, and electromagnetic fields (up to $300 \mathrm{GHz}$ ). Health Phys 1998; 74(4):494522.

2. International Agency for Research on Cancer. Press release $n^{\circ} 208$ [Internet]. Lyon [cited 2012 Feb 8]. Available from: http://www.iarc.fr/en/media-centre/pr/2011/pdfs/pr208_E.pdf.

3. Cardis E, Armstrong BK, Bowman JD, Giles GG, Hours M, Krewski D, et al. Risk of brain tumours in relation to estimated RF dose from mobile phones: results from five Interphone countries. Occup Environ Med 2011; 68(9):631-640.

4. Augner C, Florian M, Pauser G, Oberfeld G, Hacker GW. GSM base stations: Short-term effects on wellbeing. Bioelectromagnetics 2009; 30(1):73-80. 
5. Council Recommendation $1999 / 519 /$ CE of 12 July 1999 on the limitation of exposure of the general public to electromagnetic fields $(0 \mathrm{~Hz}$ to $300 \mathrm{GHz}$ ). (Official Journal of the European Communities, L199/59, 30/07/1999).

6. Directive 40/2004/EC of the European Parliament and of the Council of 29 April 2004 on the minimum health and safety requirements regarding the exposure of workers to the risks arising from physical agents (electromagnetic fields). (Official Journal of the European Communities, L159/1, 30/04/2004).

7. Real Decreto 1066/2001, de 28 de septiembre, del Ministerio de la Presidencia, por el que se aprueba el Reglamento que establece condiciones de protección del dominio público radioeléctrico, restricciones a las emisiones radioeléctricas y medidas de protección sanitaria frente a emisiones radioeléctricas. (BOE, núm. 234, 29/09/2001).

8. Úbeda A, Martínez MA, Cid MA, Chacón L, Trillo MA, Leal J. Assessment of occupational exposure to extremely low frequency magnetic fields in hospital personnel. Bioelectromagnetics 2011; 32(5):378-387.

9. Roh JH, Kim DW, Lee SJ, Kim JY, Na SW, Choi SH, et al. Intensity of extremely low-frequency electromagnetic fields produced in operating rooms during surgery at the standing position of anesthesiologists. Anesthesiology 2009; 111(2):275-278.

10. Huang SM, Lin YW, Sung FC, Li CY, Chang MF, Chen PC. Occupational exposure of dentists to extremely low-frequency magnetic field. J Occup Health 2011; 53(2):130-136.

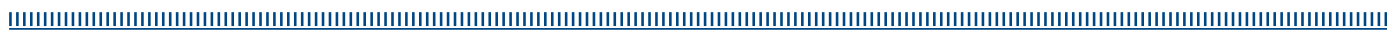

